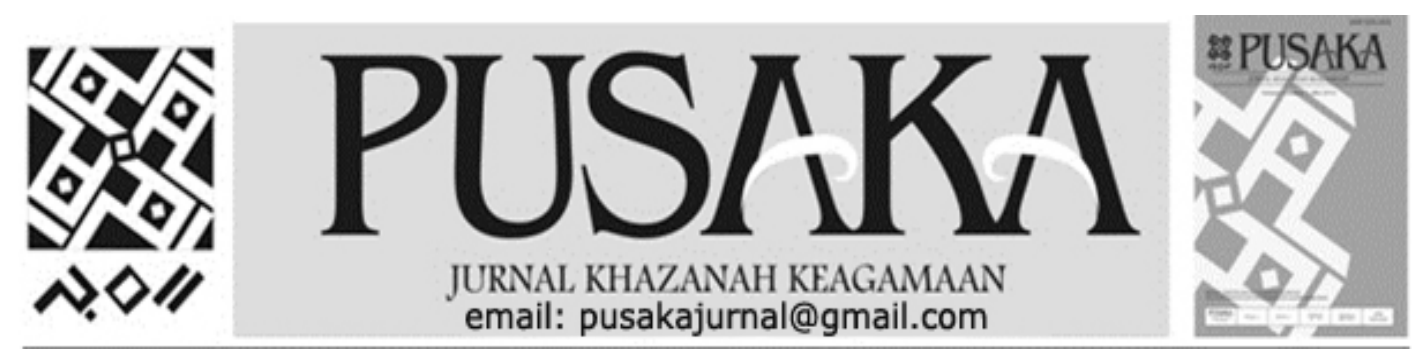

\title{
Islam dan Kristen Di Tanah Bugis Soppeng (Sejarah Dan Perkembangannya)
}

\author{
Islam and Christianity in Bugis Land of Soppeng \\ (History and Development)
}

Sitti Arafah

Balai Penelitian dan Pengembangan Agama Makassar

Jl.A.P.Pettarani No.72 Makassar. Telp:0411-452952

Email: arafahlitbang@yahoo.com

\begin{tabular}{|c|c|}
\hline $\begin{array}{c}\text { Info } \\
\text { Artikel }\end{array}$ & Abstract \\
\hline $\begin{array}{c}\text { Diterima } \\
20 \\
\text { Juni } \\
2017 \\
\text { Revisi I } \\
10 \\
\text { Agustus } \\
2017 \\
\\
\text { Revisi II } \\
26 \\
\text { September } \\
2017 \\
\\
\text { Disetujui } \\
18 \\
\text { Oktober } \\
2017\end{array}$ & $\begin{array}{l}\text { Penelitian ini bertujuan mengambarkan sejarah dan perkembangan Islam dan } \\
\text { Kristen di Tanah Bugis Soppeng. Jenis penelitian ini adalah kualitatif } \\
\text { menggunakan metode pengumpulan data observasi, wawancara dan dokumentasi. } \\
\text { Hasil penelitian menunjukkan bahwa Islam dan Kristen menjadi anutan bagi } \\
\text { masyarakat Bugis di Tanah Soppeng, yang nota bene bahwa orang Bugis tentulah } \\
\text { beragama Islam, namun tidak demikian adanya di Tanah Bugis Soppeng. Tampak } \\
\text { bahwa Kekristenan di Sulawesi Selatan lebih dahulu masuknya agama Islam } \\
\text { sebagai agama resmi di seluruh kerajaan di Sulawesi Selatan. Kristen masuk di } \\
\text { Sulawesi Selatan sekitar abad- ke } 15-16 \text { khususnya Katolik yang berlangsung } \\
\text { lebih } 100 \text { tahun } 1530 \text {-an-1668). Sedangkan Islam masuk di Sulawesi Selatan } \\
\text { disebarkan oleh tiga datuk pada akhir abad ke- 16. Namun demikian walaupun } \\
\text { kehadiran agama Kiristen di Sulawesi Selatan, namun pada kenyataan bahwa } \\
\text { masuknya Kristen dan Katolik di Tanah Bugis Soppeng diperkirakan tahun } 1935- \\
\text { 1940, sehingga Islam jauh lebih dahulu menjadi agama anutan masyarakat. } \\
\text { Kata Kunci: Islam, Kristen, Soppeng, Sejarah } \\
\text { The research aims history to ilmustrate the history and developed of Islam and } \\
\text { Cristianity in the Bugis Land of Soppeng. This type of research is using qualitative } \\
\text { observasiondata collection method, interview and documnetation. The result } \\
\text { showed that Islam and Cristianity became the model for the Bugis community in } \\
\text { the Bugis land of Soppeng that notebene that the Bugis people must be muslim, but } \\
\text { not so in the bugis land. It appears that Chistianity in South Celebes is more than } \\
\text { inclusion of Islam as the official religion throughout the kingdom in South } \\
\text { Celebes. Christians entered in South Celebes around the century 15-16 th, } \\
\text { especially Chatolicts 100 years (1530-1668). While Islam entered ini South } \\
\text { Celebes propagated by three datuk at the end of the century } 16 \text { th. But in fact that } \\
\text { the inclusion of Christian and Chatolik in Soppeng Bugis land was estimated } \\
\text { 1935-1940, so Islam far earlier became the official relion of Bugis society. } \\
\text { Keywords: Islamic, Christians, Soppeng, History }\end{array}$ \\
\hline
\end{tabular}




\section{PENDAHULUAN}

Agama merupakan fenomena universal dalam kehidupan manusia secara menyeluruh, dari primitif hingga yang ultra-modern, mulai dari manusia pertama Nabi Adam dalam keyakinan pemeluk agama Abraham (Yahudi, Nasrani, dan Islam), hingga kita yng hidup sekarang diawal milinuim ketiga. Agama juga menjadi ciri umum bagi manusia yang hidup di segala penjuru bumi, orang barat dan orang timur samasama memiliki keyakinan atas adanya suatu yang sakral dan bahwa pemikiran dan tingkah laku manusia dipengaruhi oleh keyakinan sebagai mahluk yang beragama (homo religious) (Arifinsyah, 2008: 70).

Manusia tampaknya diketahui telah memiliki "agama", atau sesuatu yang mirip itu. Ini menunjukkan bahwa suatu agama memenuhi suatu kebutuhan universal manusia atau setidaknya timbul dari suatu bagian kodrat manusia yang kita semua miliki. Bagi seorang penganut agama, pertanyaan-pertanyaan mengenai fungsi agama mungkin tampak tidak masuk akal atau bahkan menyinggung. Seseorang penganut agama mungkin memberikan tanggapan bahwa agama nyaris universal di antara masyarakat semata karena Tuhan betul-betul ada, dan adanya agama dimana-mana tidak perlu dicari-cari fungsi dan manfaatnya seperti juga batu ada dimana-mana. (Diamond, 2015: 412414).

E.B Taylor dalam buku perintisnya, Primitive Culture, mengemukakan apa yang dikenal dengan agama yang tidak akan memberikan penilian lagi mengenai sumber dan fungsinya. Dia mendefinisikan agama sebagai "kepercayaan terhadap adanya wujud-wujud spritual". Adapun Durkheim, yang menekankan ciri kolektif atau sosial pada agama ia menyatakan bahwa "agama adalah sistem yang menyatu mengenai berbagai kepercayaan dan peribadatan yang berkaitan dengan benda-benda sakral, yakni katakanlah benda-benda yang terpisah dan terlarang mempersatukan semua orang yang menganutnya ke dalam suatu komunitas moral yang disebut dengan gereja". (Shcar, 2004: 33$34)$.

Geertz mengemukakan bahwa "Agama adalah suatu sistem simbolsimbol yang bertindak untuk memantapkan suasana hati dan motivasi yang berkuasa, pervasif, dan bertahan lama pada manusia dengan cara merumuskan konsepsikonsepsi mengenai suatu tatanan umum keberadaan dan membungkus konspesi-konsepsi ini dengan aura faktualitas sedemikian rupa sehingga suasana hati dan motivasi itu tampak teramat realistik. (Diamond, 2015: 417).

Agama menjadi penting bagi setiap umat manusia sebagai pegangan dalam kehidupan manusia, sebagai sebuah keyakinan yang harus dijalankan oleh setiap umatnya yang memiliki beragam simbol dan nilainilai spritual yang melekat dan megikait pada masing-masing agama.

Kehadiran agama-agama secara umum di Indonesia tidak terlepas dari peran para pendatang khususnya para pedagang seperti Gujarat, Arab yang datang membawa dan menyebarkan Islam di seluruh kepulauan nusantara, demikian 
halnya para pendatang dari Belanda, Portugis dan sebagainya, yang berperan sebagai missionaris untuk menyebarkan agama-agama Katolik dan Protestan yang juga menyebar pada beberapa kepulauan di nusantara.

Konsep Ketuhanan masyarakat Sulawesi Selatan sebelum datangnya berbagai agama telah mengenal adanya konsep ketuhanan yakni 'Dewata Seuwwae' sebagai kepercayaan nenek moyang mereka. Demikian halnya dengan kehadiran agama seperti Buddha, Kristen lebih dahulu dikenal bahkan pernah menjadi agama yang dianut oleh kerajaan-kerajaan kecil yang ada di Sulawesi Selatan, seperti kerajaan Suppa yang pernah menjadikan kristen sebagai agama kerajaan.

Sejarah Kekristenan di kalangan orang Bugis sudah berlangsung sejak abad ke-16. Sejumlah raja-raja Bugis di pesisir selat Makassar, dari pare-pare sampai Makassar (bacukiki-, Gowa, Suppa dan Tallo) pernah mengenal agama Kristen, bahkan ada raja dan pangeran yang dibaptis oleh para paderi Katolik zaman Portugis. Kekristenan Katolik yang berlangsung lebih 100 tahun 1530an-1668) berakhir oleh peristiwa Silariang seorang putri raja Suppa dengan Kapiten Kapal Portugis, dan juga dipilihan raja Gowa menerima Islam dan memaksakan pengislaman kerajaan-kerajaan lainnya (awal abad ke-17) Pihak VOC dan pemerinth kolonial Belanda mempertahankan Kekeristenan Protestan di Makassar, kemudian juga di Bulukumba dan Selayar. (Ngelow, 2017).
Berdasarkan latarbelakang, maka permasalahan pokok dalam penelitian ini adalah: bagaimana sejarah dan perkembangan Islam dan Kristen di Tanah Bugis Soppeng?

Secara umum penelitian ini bertujuan untuk mengetahui dan mengungkap eksistensi meliputi sejarah dan perkembangan agamaagama di Soppeng ( Islam, Kristen dan Katolik) adapun kegunaan penelitian ini diharapkan dapat memberikan informasi terkait eksistensi agama ( Islam, Kristen dan Katolik) di Tanah Bugis Soppeng.

\section{PEMBAHASAN}

\section{Sekilas Lahirnya Wanua Soppeng}

Masyarakat Soppeng berasal dari Gattarang dan Sewo mereka hijrah bermigran meninggalkan negerinya sebab dinasti Galigo telah berakhir misinya menyebabkan tidak ada raja (Datu) yang melaksanakan pemerintahan, menyebabkan adek tidak berfungsi.

Enam pulu pammatoangeng memimpin masyarakat membangun negeri (wanua). Masyarakat Bila berasal dari Sewo dan masyarakat Gattareng membangun negeri Salotungo. Kelompok to Sewo dan kelompok to Gattareng menamakan negeri Soppeng ri Lau. Soppeng Soppeng Riaja maupun Sopeng Rilau didukung oleh Matoa 60 yang terbagi Matoa yang masing-masing membangun beberapa Wanua untuk wilayah Soppeng riaja dan sebagian matoa dan kelompoknya masingmasing membangun Matoa dalam wilayah Soppeng Rilaiu.

Lahan subur yang dipenuhi segala macam pohon buah-buahan yang menjadi markas burung kalelawar menjadi pilihan untuk 
djadikan pembangunan negeri. Pohon buah-buahan memberi ilham untuk mukatasi menjadi nama negeri yang buah caloppeng dan buah bila. Buah caloppeng berwarna ungu bentuknya budanr lonjong sejenis buah anggur. Caloppeng, mangga ataupun bila sudah sulti ditemukan di Soppeng sekarang, dahulu pohon buah-buahan tersebut yang memenuhi hutan, dapat menjadi tempat rekreasi dan memetik buahbuahan.

Kesatuan dan persatuan dijadikan dasar hidup berkeluarga, bermasyarakat tiap Wanua dari pimpinan 60 pammatoangeng yang terikat sebagai persekutuan negeri. Wanua Soppeng. Wanua artunya negeri hunian atau tanah tempat perkampungan masyarakat yang dipimpin oleh seseorang yang dituakan namanya Matoa.Wanua bangkung artinya sarung parang atau tempat parang (sarung kesris atau sarung badik) wanua yang dipimpin oleh Matoa namanya Negeri. Negeri Bila, Wanua Tinco, Wanua Salotungo, dan lainnya semuanya di Soppeng. (Sumange, 2007: 117-120).

\section{Kepercayaan Bugis Kuno Sebelum Mengenal Islam}

Religi pada dasarnya merupakan suatu konsep yang menunjukkan fikiran manusia yang mengakui adanya kekuatan di luar dirinya yang mengatur, memberikan kesejahteraan hidupnya dan juga mendapatkan bala bencana dan lainlain. Kekuatan itu tidak terjangkau oleh indera dan daya akal, tetapi diterima kebenarannya tentang adanya kekuatan tersebut. Kalompoang atau Arajang, termasuk mahkota kerajaan sebagai benda suci memiliki kekuataan gaib, yang menguasai alam manusia serta dipuja sebagai pelindung jiwa masyarakat. Di Sulawesi Selatan terdapat sistem kepercayaan tradisional yang bersumber pada mitologi I Lagaligo, kepercayaan tidak akan lenyap dan yang nilai-nilainya berfungsi untuk mempertahankan keberlangsungan hidup untuk masyarakat (Sumange, 2007: 29-30).

Sebelum masyarakat Bugis mengenal Islam mereka sudah mempunyai "kepercayaan asli" (ancestor belief) dan menyebut Tuhan dengan sebutan Dewata SeuwaE" yang berarti Tuhan kita yang satu. Bahasa yang digunakan untuk menyebut "Tuhan" itu menunjukkan bahwa orang Bugis memiliki kepercayaan kepada "Tuhan Yang Maha Esa" secara monoteistis. Menurut Mattulada, religi orang Bugis masa Pra Islam seperti tergambar dalam Sure Lagaligo, sejak awal telah memiliki suatu kepercayaan kepada suatu dewa (Tuhan) yang tunggal, yang disebut dengan beberapa nama: PatotoE (dia yang menentukan nasib), Dewata Seuwae (Dewa yang tunggal) To- PalinroE (sang pencipta dan lain-lain.

Sebelum masyarakat Bugis mengenal Islam mereka sudah mempunyai "kepercayaan asli " (ancestor belief) dan menyebut Tuhan dengan sebutan Dewata SeuwaE" yang berarti Tuhan kita yang satu. Bahasa yang digunakan untuk menyebut "Tuhan" itu menunjukkan bahwa orang Bugis memiliki kepercayaan kepada "Tuhan Yang Maha Esa" secara monoteistis. Menurut Mattulada, religi orang Bugis masa Pra Islam 
seperti tergambar dalam Sure Lagaligo, sejak awal telah memiliki suatu kepercayaan kepada suatu dewa (Tuhan) yang tunggal, yang disebut dengan beberapa nama : PatotoE (dia yang menentukan nasib), Dewata Seuwae (Dewa yang tunggal) To- PalinroE (sang pencipta dan lain-lain.

\section{Asellengngng'e ri Soppeng (Awal Masuknya Islam di Soppeng)}

Agama Islam diperkirakan masuk di Sulawesi Selatan pada akhir abad XVI melalui para saudagar Bugis-Makassar ataupun orang-orang Melayu yang masuk ke kerajaan Gowa setelah meninggalkan negerinya akibat "Perang Salib" yang dilancarkan oleh Portugis, namun agama ini hanya dianut secara perorangan atau kelompok-kelompok kecil dan sembunyi-sembunyi.

Kedatangan 3 Datuk di daratan Sulawesi Selatan, untuk menyebarakan ajaran Islam pada awal abad ke 17. Dalam Lontara Wajo menyebutkan bahwa para pedagang Melayu mulai merasa tidak senang dengan orang Bugis dan Makassar yang terpengaruh dengan agama Kristen Katolik yang dibawa oleh para misionaris. Sehingga oleh pedagang Melayu ini mengundang mereka bertiga ( datuk) untuk datang menyebarkan Islam yang dalam lontara wajo dikenal dengan Tellu Datuk (Bugis) dan Datuk Tallu'a (Makassar). (diakses dari blogspott.lelakibugis.net/tiga-datuk)

Penerimaan Islam di Tanah Bugis Soppeng, tidak terlepas dai sejarah panjang perkembangan Islam di Sulawesi Selatan. Dimana penerimaannya oleh kerajaankerajaan lokal secara resmi terjadi pada awal abad ke-17, yang sebelumnya telah didatangi oleh orang Islam dari luar, bahkan sudah menetap. Bahkan raja Gowa Karaeng Tunijallo (1565-1590) mendirikan masjid di Mangallekana untuk para pedagang asing agar dapat tentram menetap di Gowa. (As'ad, 2011: 25).

Penerimaan agama Islam oleh kerajaan-kerajaan utama di Sulawesi Selatan dimulai oleh kerajaan Luwu pada tahun $1603 \mathrm{M}(1.013 \mathrm{H})$, kemudian disusul oleh kerajaan Kembar Gowa-Tallo pada tahun $1605 \mathrm{M}(1014 \mathrm{H})$. Atas pengaruh kerajaan Gowa, secara berturut-turut kerjaan-kerajaan Sidenreng dan Soppeng pada tahun 1609 M. (As'ad, 2011: 25).

Berdasarkan pada perjanjian yang pernah disepakati bersama antara beberapa kerajaan yang menyatakan " Bahawa barangsiapa (diantara raja-raja itu) ada yang menemukan sesuatu jalan yang baik, maka berkewajibanlah yang menemukan jalan itu memberitahukan pula kepada rajaraja lainnya yang turut berikrar pada perjanjian tersebut" maka Sultan Alauddin selaku Raja Gowa XVI mengajak seluruh raja-raja lain yang terikat dalam perjanjian tersebut memeluk agama Islam. Ajaran Raja Gowa ini ternyata hanya mendapat sambutan dari raja-raja kerajaan dari kerajaan yang merasa besar dan kuat seperti kerajaan Bone, Kerajaan Wajo dan Soppeng yang tergabung dalam kerajaan Tellumpocco-e sama sekali tidak mengubrisnya.

Karena kerajana Gowa beranggapan bahwa pengingkaran atau pembangkangan terhadap suatu perjanjian adalah merupakan perlawanan. Maka pada tahun 1608 
dikirimlah bala tentaranya untuk berperang melawan persekutuan Tellumpocco-e namun dalam peperangan tersebut kerajaan Gowa terkalahkan dan perang ini dikenal dengan istilah "musu sellengen" (Bugis) dan bundu' kasallangan (Makassar)

Setelah kekalahan Raja Gowa melawan kerajaan Tellumpocco-e bukan berarti misi sucinya untuk menyebarkan agama Islam. Sehingga strategi perangnya diubah dengan cara menaklukkan kerajaan-kerajaan yang ditaklukannya dilakukan perdamaian dengan memberi pengertian bahwa tujuannya hanyalah untuk menujukkan jalan yang lebih baik sebagaimana yang telah ditemukannya yaitu memeluk agama Islam, sesuai perjanjian yang pernah disepakati bersama.

Strategi yang dijalankan oleh kerajaan Gowa ini rupanya cukup ampuh menaklukkan kerajaankerajaan lain untuk memeluk agama Islam. Ini terbukti dengan masuknya Islam secara berturut-turut salah satu diantaranya pada tahun 1609 kerajaan Soppeng oleh Béo-é pselaku Datu Soppeng III. Setelah kerajaan Soppeng secara resmi memeluk agama Islam, maka terjadilah suatu perubahan yang sangat mendasar dalam sistem pemerintahan dan bermasyarakat di Kerajaan Soppeng . Perubahan yang sangat mendasar itu adalah terutama tentang hal pangadereng yang terdiri dari 4 unsur yaitu : ade', rapang, bicara dan wari. Tetapi setelah agama Islam diterima secara resmi dan menyeluruh di kerajaan Soppeng, maka ditambahkan 1 unsur yaitu sara'. Hal ini dapat disimak dalam ungkapan yang mengatakan Eppa- mua parajai tana, iyya mani naripagenne lima rirapu mani asellengenge' nari tambai-na kuaritu sara', iyyanaritu pammula, ade'; madduanna rapang;matellunna , bicara, maeppa-na wari; mallimanna sara'. Artinya hanyalah empat yang membesarkan (memakmurkan) negeri, nantilah dicukupkan menjadi lima setelah agama Islam diterima (dianut) dn ditambahkan yaitu: sara' yaitu: awalnya ade'; kedua rapang: ketiga bicara, keempat: wari dan kelima sara'. (Nur, 2007: 77-79).

\section{Masuknya Kristen di Tanah Bugis Soppeng}

Sebagaimana hal dengan Islam, Kristen atau yang dikenal dengan Nasrani merupakan agama langit yang diturunkan oleh Allah Swt kepada salah satu Nabinya yakni Isa a.s, kepada bangsa Israel dan oleh Islam diakui kebenarannya. Seiring dengan itu, agama Kristen menjadi agama dunia, termasuk di Indonesia dan khusus di Sulawesi Selatan agama Kristen lebih dahulu masuk ketimbang agama Islam, dimana penyebarannya dilakukan oleh

Dalam tulisan "Orang Bugis
Percaya Puang Isa", oleh
Persekutuan Generasi Muda Kristen Soppeng (PGMKS) menguraikan; Orang akan heran, takkala kita ditanya. Kamu orang apa?? Orang Bugis Ha kok bisa orang Bugis ada yang Kristen. Tapi itulah sebenarnya suatu kenyataan tidak nyata bagi orang lain yang memiliki persepsi bahwa ornag Bugis tidak ada yang Kristen. Suatu kebanggaan buat kita yang telah menerima Dia sebagai 


\section{satu-satunya penyelamat di dunia dan diakhirat.}

Tuhan Allah adalah Tuhan atas segala ciptaan-Nya termasuk umat manusia pada khususnya siapa bilang Tuhan Yesus (Puang Isa) Tuhan hanya bagi orang yang percaya kepada-Nya? Sifat ketuhanannya tidak berlaku hanya bagi orang yang menerimanya sebagai pemberi keselamatan (asalamakeng mannenungeng) namun berlaku kepada semua manusia secara universal (umum) hanya orang yang tidak mengenal-Nya tidak menerimaNya sebagai Tuhan. (diakses pada tanggal 15 April 2017)

Tahun 1935 menjadi peristiwa penting yang terjadi di kalangan orang Bugis khususnya di Tanah Bugis Soppeng. Tahun 1935 seorang bangsawan Bugis, Petta Lolo Marhabang, dibaptiskan di Soppengriaja, namun yang lebih kenal sebagai pencari kebenaran setelah pembaptisan ke-3, yakni La Galitik, La Mappe'e dan La Tasakka' di gereja Indishce Kekr (sekarang GPIB) Immanuael Makassar pada tanggal 17 Februari 1940. ( Zakariah J. Ngelow: dalam Refleksi GKSS, diakses pada tanggal 18 April 2017).

Tidak jauh beda dengan apa yang dituturkan bapak Benyamin (putra dari cambang Galitik) pencari kebenaran di tanah Soppeng menuturkan bahwa secara pasti beliau tidak mengetahui tanggal berapa dan bulan berapa tetapi masuknya Kristen di Soppeng sekitar tahun 1939, pada waktu pembantisan ketiga dilakukan pada tahun 1940 yang dilakukan oleh Dan van Brink seorang Belanda. Masuknya Kristen di Soppeng dibawah oleh ayahnya bernama Cambang Galitik dan 2 orang lainnya yakni La Mappe dan La Tasakka di Gowa.

Lanjut beliau menuturkan bahwa awal penerimaan agama tersebut adalah ketika beliau berangkat ke Gowa karena adanya urusan yang tidak terselesaikan, namun ketika tiba disana beliua disampaikan bahwa ada agama baru, maka dia kembali ke Soppeng dengan jalan kaki dan singgah pada beberapa tempat setibnya dan menyampaikan kepada keluarga bahwa ada agama baru. Namun pada awalnya bukan agama itu yang dicarinya akan tetapi ada perkara yang tidak mau putus maka bertemula dengan seorang keluarga yang berprofesi sebagai "Opasa" kini disebut dengan polisi bernama $\mathrm{La}$ Sellomo, maka disampaikanlah urusan yang dimaksud kepada La Sellomo dan selanjutnya La Sellomo memberikan arahan untuk menuju Makassar- Gowa. Maka berangkat ketiga orang ini, dan hendaknya engkau menemui orang tua yang "pintar" dan mengetahui setiap masalah atau perkara yang datang pada. Dan disanalah ia menyampaikan maksud kedatangannya terkait perkara yang diurusnya karena di Soppeng sudah puluhan tahun namun belum terselesaikan, dan sang orang tua menyuruh untuk mengurusnya dan pada akhirnya perkra tersbeut berhasil, maka timbullah keyakinan bahwa orang yang didatangi itu memiliki kemampuan yang berlebih sehingga apa yang diucapkannya diterima dan diikuti. Maka disampaikanlah bahwa ada agama yakni Kristen yang dibawah oleh Belanda. 
Ada ungkapan yang disampaikan oleh orang tua tersebut kepada Cambang Galitik, bahwa kita tidak boleh berpisah dengan orang yang berkulit putih, karna kita ini orang hitam karena mata itu ada yang hitam dan ada yang putih dan keduanya tidak boleh dipisahkan, sehingga ungkapan tersebut dipercaya oleh mereka. maka kembali ke Soppeng dan menceritakan kepada semua keluarganya. Namun tokoh-tokoh agama yang ada di Soppeng mengatakan bahwa ada yang akan merusak agama, ada mata-mata dari Belanda dan akhirnya Cambang Galitik di penjara, namun akhirnya di lepaskan sehingga ia melanjutkan penyampaian ajaran agama tersebut "Kristen" kepada keluarga dan masyarakat Bugis lainnya.

Agama Kristen oleh Cambang Galitik dan 2 orang lainnya di terima di Gowa, dan diperintahkan masuk di Gereja Cia Manu yang sekarang disebut "GPIB" untuk melaporkan diri dan akhirnya mereka pergi di gereja tersebut maka masuklah dan dibaptis.

Salah satu alasan masuknya Cambang Galitik memilih Kristen sebagai jalan hidupnya karena dia telah mengalami penderitaan yang berkepanjangan, siksaan yang didapatkan dari para "Gurilla", penembakan namun takdir belum memisahkannya sehingga dia berkeyakinan bahwa semua itu karena kehendak Allah.

Pada awalnya yang menerima Kristen sangat banyak, namun setelah pemberontakan DI/TII maka banyak orang Kristen yang kembali pada Islam kecuali mereka yang lari menuju kota maka ia tetap memeluk
Kristen termasuk Cambang Galitik yang menerima penderitaan dari gerombolan, namun tetap selamat. ( Wawancara: P.Benyamin Generasi Kedua Pembawa Kristen di Soppeng, tanggal 27 Januari 2016 di Kelurahan Lalabata Watansoppeng).

Selanjutnya dalam refleksi sejarah GKSS oleh Zakariah J. Ngelow, tentang kesaksian dari Soppeng, menyatakan bahwa orang Soppeng masuk Kristen dalam rangka mencari kebenaran injil, mengikuti tradisi messianik Petta Barang. Itu suatu kebanggaan tang juga dapat ditambahkan bahwa Kekristenan di kalangan orang Soppeng telah teruji melalui taruhan nyawa pada zaman gerombolan DI/TII ditahun 1950-an.

\section{Awal Masuknya Katolik di Tanah Bugis Soppeng}

Penceritaan dan referensi tentang masuknya Kristen "Katolik" di Soppeng sangatlah minim, namun upayakan penulisan sejarahnya sementara digarap oleh Keuskupan Agung Makassar.

Dalam catatan Pastor Imanuel Ari' Pr, yang tertulis dalam lembaran memberikan gambaran tentang masuknya Katolik di Soppeng. Yakni:

1. Tahun 1930, ada beberapa pastor dari Makassar yang kadangkadang berkunjung ke Watansoppeng dan sekitarnya;

2. Tahun 1938, pada tanggal 25 April 1938 Mgr. Gerard Martens, CICM dan pastor $\mathrm{Chr}$ Eykemans, CICM datang ke Soppeng;

3. Tahun 1940 Pastor Van Schaik, CICM dan pastor Van der 
Krabben, CICM secara bergantian dan kadang-kadang bersama-sama datang ke Watansoppeng;

4. Tahun 1958, pada tanggal 18 Desember $1958 \quad$ terjadi pembaptisan pertama;

5. Tahun 1963, gereja Katolik Soppeng mulai dibangun;

6. Tahun 1970, Pastor L. Blot, CICM sudah mulai sering datang di Watansoppeng;

7. Tahun 1971, kegiatan ziarah sudah dimulai (khusus umat paroki Soppeng);

8. Tahun 1975, Pastor L.Blot telah menyelesaikan pembangunan tempat patuan Maria Pieta yang berada di samping gereja sebagai tempat untuk mengunjungi dan berharap pada doa Bunda Maria melalui kegiatan ziarah. Pada tahun ini juga Pastor L.Blot, CICM sudah mengundang umat dari paroki lain untuk datang ziarah di Soppeng;

9. Tahuj 1976, diperkirakan bahwa pada tanggal 30 Mei 1976 tempat ini sudah dijadikan sebagai tempat ziarah;

10. Tahun 1979, pada tanggal 14 April 1976 disinyalir paroki ini diresmikan dengan nama pelindung paroko Santa Maria Bunda Pengharapan Suci Soppeng;

11. Tahun 1984, Pastor L. Blot, CICM membuat daftar stasi-stasi Paroki SPM. BPS Soppeng yaitu: Watansoppeng Pacongkang, Cendrana, Pattojo, Sidrap, Rappang, Sengkang. Lauwa, Siwa/Bonepute, Watampone, Arasoe/Camming. Leppangeng dan Sinjai;
12. Tahun 1987, Pastor Alex Lethe, Pr, mengantikan Pastor L.Blot, CICM sebagai pastor Paroki;

13. Tahun 1990, Pastor Herman Tony, Pr (ex) menjadi pastor Paroki. Dalam tahun ini ada pembakaran gereja di Soppeng dan Pacongkang;

14. Tahun 1994, Pastor Octavianus Samson Bureny, Pr menjadi Paroki Soppeng.Pastor Samson membangun sebuah pendopo di depan patung Bunda Maria Pieta;

15. Tahun 2000, Pastor Cornell R Tandiayuk, Pr menjadi Pastor Paroki Soppeng. Beliau membeli tanah sebelah timur dengan tujuan pembangunan saranasarana devosi kepada Maria;

16. Tahun 2003, Pastor Nikodemus Tangke, Pr menjadi pastor Paroki Soppeng beliau mengembangkan sarana-sarana pendukung tempat ziarah misalnya dengan mengubah rute jalan salib;

17. Tahun 2005, Pastor Agustinus Kale'pe, Pr, menjadi Pastor Paroki Soppeng. Beliau melanjutkan pelayanan yang sudah dimulai pendahulunya dan

18. Tahun 2012, Pastor Imanuel Ari', Pr menjadi pastor Paroki Soppeng. Dalam tahun ini telah diurus sertifikat tanah gereja dan serius memikirkan pembangunan gereja pusat Paroki Soppeng. (Sumber: Dokumen yang disusun oleh Pastor Imanuel Ari, Pr.)

\section{Perkembangan Islam, Kristen dan Katolik di Tanah Bugis Soppeng}

Watak orang Bugis dan sifat kebudayaannya dapat ditelusuri 
dalam sejumlah lontara. Jikalau dapat ditemukan dalam sumber ini, berarti watak san sifat mereka sebagai suatu bangsa digambarkan sendiri oleh mereka yang meliputi masa yang panjang. Oleh bangsabangsa lain, entah karena petualangan atau karena keserakahan hawa nafsu atau karena misi suci, negeri Bugis mulai tersentuh oleh mereka yakni bangsa Portugis, Perancis, Inggeris dan Belanda.

Oleh Tome Pires, menyebutnya orang Bugis-Makassar bahwa mereka itu adalah kafir. Pada tahun 1543 seorang pedagang kayu dari Inggeris Antonio Payva bersama 12 orang temanya tiba di Parepere dan berhasil mengkristen Raja Bugis di Suppa, La Makkarawi-e bersama keluarganya (istri dan anaknya) dan raja Suppa sendiri diberi nama Don Luis. Kemudian ekspansinya memasuki daerah Pangkajene dan mengkristenkan Raja Siang. Beliau dimandikan dan dibaptis di gereja Santo Rapael dan gereja ini diberi nama Don Juan. Namun kekhawatiran Deyva muncul ketika ada pendatang lain yakni orangorang Melayu Islam Pahang dan Patani. (Rahim, 1992, 2-3).

Seorang Portugis Juan de Eredia, yang berhasil melarikan Dona Elena Vesiva, gadis raja Suppa mengakibatkan usaha pengkristenan terhadap orang-orang Bugis patah di tengah jalan. Oleh pendeta Pater Viegas ketika mengetahui baghwa orang Bugis menghunus senjata hendak menangkap orang-orang Portugis maka ia segera memerintahkan agar cepat-cepat berlayar meninggalkan pelabuhan menuju Malaka, dan hal inilah yang mengakibatkan persahabatan antara keduanya Bugis dan Portugis, bersamaan dengan dihancurkannya gereja Santo Rafael. (A.Rahman Rahim, 1992: 3)

$\begin{array}{lrr} & \text { Selain usaha yang dilakukan } \\ \text { oleh orang Portugis } & \text { dengan } \\ \text { mengkristenkan beberapa } & \text { kerajaan } \\ \text { Bugis di Sulawesi } & \text { Selatan. }\end{array}$
Nederlandsch Bijbelgenootschap yang tujuan utamnya menyebarkan agama Kristen, mamandang perlu melakukan penterjemahan Injil dalam bahasa-bahasa Nusantara. Pada tahun 1848 Dr.B.F.Mathees diutus ke Makassar untuk tujuan tersebut (Rahim, 1992:7).

Masyarakat Bugis pada awalya diliputi oleh sejumlah mitos. Sure Galigo menceritakan tentnag awal mula dihuninya negeri Bugis, ketika Batara Guru dari Botinglangi' (dunia atas) bertemu di Tana Luwu dengan We'Nyellitimo dari Buri'liung (dunia bawah). Simpurusiang di Luwu, Sengingridi di Bone, Petta Sekkanyili di Soppeng. Puteri i

Sebagai salah satu kerajaan lokal di Sulawesi Selatan, kerajaan Soppeng menjadikan agama Islam sebagai agama resmi yang dianut oleh masyarakatnya hingga kini. walau sebelumnya masyarakat menganut paham Dewata Sewwa'E, dengan konsep to manurung. Namun setelah terjadi pengislaman oleh kerajaan Gowa kepada kerajaankerajaan lokal, maka Islam menjadi agama resmi bagi semua kerajaan di Sulawesi Selatan termasuk dalam hal ini kerajaan Soppeng.

Soppeng dikenal sebagai daerah Bugis dalam penerimaan agama cukup dinamis, hal ini ditandai dengan adanya berbagai agama yang dianut oleh masyarakat, baik masyarakat asli (Bugis) maupun 
masyarakat pendatang dari berbagai etnis, seperti China, Toraja, dan sebagainya. Sehingga di tanah Bugis agama yang berkembang bukan hanya Islam, tetapi berbagai agama utamanya di Soppeng.

Islam sebagai agama mayoritas yang dianut oleh masyarakat dari sejak penerimaannya hingga kini, menjadi sumber nilai dari berbagai aktivitas kehidupan masyarakat. Nilai-nilai yang dianut oleh masyarakat Bugis tidak dapat dipisahkan dalam 5 konsep yakni: ade, rapang, bicara, wari dan sara'.

Selain Islam sebagai agama mayoritas yang dianut oleh masyarakat Bugis, tampak pula diantara orang-orang Bugis walaupun dinilai tidak lazim memeluk agama lain yakni Kristen (Protestan dan Katolik). Masuknya agama Kristen di Tanah Bugis Soppeng belum terdapat data (dokumen) tertulis, namun diperkirakan masuk sekitar tahun 1935-1940 baik Protestan maupun Katolik. Kehadiran agama ini ditanah Bugis Soppeng, dianut bukan hanya pendatang seperti suku Toraja, Manado, dan sebagainya tetapi juga dianut oleh masyarakat suku Bugis asli, dan menyebar pada beberapa kelurahan dan kecamatan di Soppeng. Kehadiran juga mewarnai kehidupan keagamaan bagi masyarakat di tanah Bugis Soppeng.

Kekristenan di Bugis Soppeng sejak awal terkait dengan jaringan keluarga. Hubungan keluarga dapat memajukan gereja, tetapi sebaliknya juga dapat merusaknya. Setiap pelayanan dalam komunitas masyarakat Bugis Soppeng ini harus memberi perhatian pada aspek hubungan kekeluargaan itu. Dapat disimpulkan bahwa kekristenan di kalangan orang Bugis Soppeng berakar kuat, namun terpancar dalam berbagai gereja. Dukungan wadah sosial seperti kerukunan warga Kristen Soppeng dapat menjadi jembatan untuk persaudaraan ganda sebagai saudara dalam identitas Soppeng dan dalam persaudaraan iman kepada Kristus. (Ngelow, 2017).

Agama Kristen khususnya di Soppeng tersebar pada 3 kelurahan/Desa yakni (1) Desa Woddi Kecamatan Marioriwawo, (2) Desa Barang Kec. Pacongkan. dan (3) Kelurahan Lalabata Kota Watansoppeng. Terdapat 4 gereja yakni gereka GKSS (Gereja Kristen Sulawesi Selatan), Gereja Katolik dan Gereja Toraja dan Gereja Petra. sedangkan gereja yang pertama masih berdiri dengan bangunan kayu, namun tidak lagi dipergunakan sebagai tempat ibadat (Protestan) berada di Desa Barang, sedangkan bangunan gereja pertama untuk Katolik adalah bangunan semi permanet berada di Kelurahan Lalabata dan kini telah memiliki bangunan gereja yang sangat besar, bahkan terdapat patung bunda Maria Pieta sebagai tempat ziarah bagi umat Katolik dari berbagai daerah di Kawasan Timur Indonesia pada bulan April sampai Mei setiap tahunnya.

Perkembangan Kristen dan Katolik ditanah bugis Soppeng, tampak tidak mengalami perkembangan secara signifikan, dan kini pemeluk Kristen dan di Katolik di Tanah Bugis Soppeng bukan hanya dari kalangan Bugis, tetapi telah mengalai interaksi dengan suku lainnya seperti Suku Toraja, 
Mamasa, Minahasa, Manado maupun suku lainnya sebagai akibat dari adanya kawin mawin, khususnya bagi generasi belakangan ini.

Walaupun secara kuantitaf jumlah mereka sangat sedikit, namun dapat dinyatakan bahwa di Tanah Bugis Soppeng umat beragama hidup secara berdampingan dalam bingkai, namun perbedaan itu tidak dapat dipisahkan diantara mereka karena terbalut dalam hubungan kekerabatan dan kekeluargaan walaupun keyakinan diantara mereka berbeda, karena setiap umat punya jalan untuk memperoleh kebenaran itu. Islam dan Kristen serta Katolik hidup rukun dalam sebuah konsep "padaidi" yang artinya antara kita.

Di samping itu, bahwa kuantitatif umat Kristen dan Katolik masih sangat sedikit, namun selain sarana ibadat juga terdapat sarana pendidikan yakni 1 buah sekolah dasar Oikemene walaupun berdiri dengan gedung yang sangat sederhana, namun aktifitas pembelajaran berjalan dengan baik. Oleh karena itu perhatian pemerintah dalam hal ini Kementerian Agama juga turut memberikan pelayanan walaupun masih sangat terbatas sebagaimana diungkapkan oleh Kasi Bimas Islam bahwa Kemenag sudah menfasilitasi mereka dalam berbagai hal, antara lain: penyiapan penyuluh honorer, memfasilitasi melalui pengakatan Guru Agama 1 orang, menghadiri kegiatan-kegiatan keagamaan (memberikan sambutan) dan lain sebagainya namun tentunya bahwa pelayanan ini dinilai masih sangat terbatas. (Akhmad Acok Iskandar, 26 Januari 2017).

\section{PENUTUP}

Sebagai kesimpulan dari bahasan ini yaitu:

1. Kehadiran agama-agama secara umum di Indonesia tidak terlepas dari peran para pendatang khususnya para pedagang seperti Gujarat, Arab yang datang membawa dan menyebarkan Islam di seluruh kepulauan nusantara, demikian halnya para pendatang dari Belanda, Portugis dan sebagainya, yang berperan sebagai missionaris untuk menyebarkan agama-agama Katolik dan Protestan yang juga menyebar pada beberapa kepulauan di nusantara. Konsep Ketuhanan masyarakat Sulawesi Selatan sebelum datangnya berbagai agama telah mengenal adanya konsep ketuhanan yakni "Dewata Seuwwae”. Penerimaan Islam di Sulawesi Selatan tentunya tidak lepas dari peran tiga ( 3 datuk) yang dalam lontara wajo dikenal dengan Tellu Datuk (Bugis) dan Datuk Tallu'a ( Makassar). Sedangkan penerimaan Islam di Kerajaan Soppeng atas pengaruh kerajaan Gowa, Soppeng pada tahun $1609 \mathrm{M}$.

2. Sejarah Kekristenan di kalangan orang Bugis sudah berlangsung sejak abad ke-16. Sejumlah raja-raja Bugis di pesisir selamat Makassar, dari pare-pare sampai Makassar (bacukiki-, Gowa, Suppa dan Tallo) pernah mengenal agama Kristen, bahkan ada raja dan pangeran yang dibaptis oleh para paderi Katolik zaman 
Portugis. Kekristenan Katolik yang berlangsung lebih 100 tahun 1530-an-1668) berakhir oleh peristiwa Silariang seorang putri raja Suppa dengan Kapiten Kapal Portugis. Sedangkan penerimaan Kristen dan Katolik di Tanah Bugis Soppeng sejak tahun 19351940 ditandai dengan adanya pembaptisan oleh beberapa orang Bugis yang berasal dari Soppeng.

3. Perkembangan 3 agama (Islam, Kristen dan Katolik) di tanah Bugis tampak bahwa Islam menjadi agama mayoritas di kalangan orang Bugis, sedangkan Kristen dan Katolik juga menjadi agama bagi suku Bugis khususnya di Soppeng yang dibangun atas sistem kekerabatan dan kekeluargaan melalui kawin- mawin, namun perkembangan keduanya dinilai tidak signifikan.

\section{DAFTAR PUSTAKA}

Arifinsyah. 2008, Satu Tuhan Banyak Agama, dalam Jurnal Harmoni, Volume VII nomor 28 Oktober- Desember 2008.

As'ad, Muh. 2011. Buah Pena Sang Ulama, Jakarta: Orbit Publishing.

Scharf, Betty R. 2004. Sosiologi Agama, Jakarta: Kencana.
Connolly, Peter. 2016. Aneka Pendekatan Studi Agama, Yogyakarta: LkiS.

Diamond, Jared. 2015. The World Until Yesterday, diterjemahkan oleh Damaring Tyas WP dengan judul "Dunia Hingga Kemarin”, Jakarta: Gramedia.

Menzies, Allan. 2014, Sejarah Agama-Agama Studi Sejarah, Karakteristik dan Praktik Agama-Agama Besar di Dunia, Yogkarta: Forum.

Nur, M. Rafiuddin. 2007. Lontara'na Soppéng dari Kerajaan kembar menuju Kabupaten; Makassar: Rumah Ide.

Rahim, A.Rahman, 1992. Nilai-nilai Utama Kebudayaan Bugis, Ujung Pandang: Hasanuddin University Press.

Sumange, Hary. 2007. Sejarah Arajangna Soppeng: Yayasan Bina Budaya Soppeng.

Dok. Pastor Immanuel Ari Pr, catatan masuknya Katolik di Soppeng.

Internet:

Tiga datuk diakses dari blogspott.lelakibugis.net/tigadatuk)

"Orang Bugis Percaya Puang Isa", oleh Persekutuan Generasi Muda Kristen Soppeng (PGMKS) diakses pada 15 April 2017 
Zakariah J. Ngelow: dalam Refleksi Sejarah GKSS dan Pekabaran Injil di Tanah Bugis-Makassar dan Selayar, diakses melalui: gkss-mattirobaji.blogspot.com. pada tanggal 18 April 2017 